\title{
ПРЕДЛОЖЕНИЯ ПО ОПТИМИЗАЦИИ БОРЬБЫ С ТЕРРОРИЗМОМ И ЕГО ФИНАНСИРОВАНИЕМ КАК ОДНИМ ИЗ НАПРАВЛЕНИЙ УКРЕПЛЕНИЯ НАЦИОНАЛЬНОЙ БЕЗОПАСНОСТИ РОССИИ (ПО МАТЕРИАЛАМ РЕСПУБЛИКИ ИНГУШЕТИЯ)
}

\begin{abstract}
Аннотация: В статье автор на основе научных исследований делает предложения по оптимизации борьбы с терроризмом и его финансированием как одним из направлений укрепления национальной безопасности России (по материалам Республики Ингушетия)

Ключевые слова: Юриспруденция, борьба, выявление, предложения, безопасность, преступление, оптимизация, расследование, терроризм, финансирование
\end{abstract}

$\mathrm{T}$ ермин «национальная безопасность» означает состояние защищенности личности, общества и государства от внутренних и внешних угроз, которое позволяет обеспечить конституционные права, свободы, достойные качество и уровень жизни граждан, суверенитет, территориальную целостность и устойчивое развитие Российской Федерации, оборону и безопасность государства ${ }^{1}$.

Преступления террористического характера, являясь сегментом организованной преступности, представляют повышенную общественную опасность.

Руководством России принимаются энергичные меры по нейтрализации причинного комплекса преступлений террористического характера на Северном Кавказе путем улучшения социально-экономического положения население, создания рабочих мест, ликвидации безработицы, пропаганды идей традиционного ислама и контрпропаганда идеям ваххабизма, улучшение духовного воспитания молодежи, работа с родителями и их детьми. Важно не только существенно улучшать социально-экономическое положение республик в Северо - Кавказском федеральном округе, но и воздействовать на потребностно - мотивационную сферу проживающих там граждан, изменение их ценностных ориентаций.

Президент Российской Федерации принимает меры к совершенствованию законодательства по борьбе

\footnotetext{
${ }^{1}$ Стратегия национальной безопасности Российской Федерации до 2020 года. Утверждена Указом Президента Российской Федерации от 12 мая 2009 г. № 537. http://www.scrf.gov.ru/ documents/99.html. 04.12.2011.
}

с преступлениями, связанными с легализацией (отмыванием) доходов, полученных преступным путем, и финансированию терроризма. В соответствии с Федеральным законом Уголовный кодекс Российской Федерации дополняется статьёй 173-1 (статья 173 пункт 1), устанавливающей ответственность за незаконное образование (создание, реорганизацию) юридического лица через подставных лиц (так называемую фирмуоднодневку). Кроме того, Федеральным законом предусматривается введение уголовной ответственности за незаконные предоставление или приобретение документа, удостоверяющего личность, либо использование персональных данных, полученных незаконным путём, если эти деяния совершены для образования юридического лица в целях совершения одного или нескольких преступлений, связанных с финансовыми операциями либо сделками с денежными средствами или иным имуществом. Соответствующие изменения вносятся также в статью 151 Уголовно-процессуального кодекса Российской Федерации с целью отнесения предварительного расследования по уголовным делам об указанных преступлениях к подследственности следователей органов внутренних дел².

\footnotetext{
2 Подписан закон, устанавливающий уголовную ответственность за незаконное создание юридического лица через подставных лиц. 7 декабря 2011 года, 15:15. Президент подписал Федеральный закон «О внесении изменений в Уголовный кодекс Российской Федерации и статью 151 Уголовно-процессуального кодекса Российской Федерации». Федеральный закон принят Государственной Думой 22 ноября 2011 года и одобрен Советом Федерации 29 ноября 2011 года. http://kremlin. ru/news/13888. (дата обращения: 08.12.2011).
} 
В мае 2011 г. сотрудниками НИИ Академии Генеральной прокуратуры Российской Федерации был осуществлен выезд в Республику Ингушетия в целях криминологического изучения организованной преступности, терроризма и экстремизма и системы их детерминации. Детерминация - процесс обусловливания, определения. Процесс детерминации преступности представляет собой сложное взаимодействие различных форм связей: не только причинных, но также функциональных, статистических, связей состояния и других ${ }^{3}$.

В криминологии причинность рассматривается как взаимодействие социальной среды и личности. Взаимодействие характеризуется двуединством активной и пассивной сторон, их взаимной дополняемостью. При этом вычленяются: а) взаимодействие внешнего и внутреннего (применительно к причинам преступности это взаимодействие среды и населения, разных типов личности), б) внутренние взаимодействия - это взаимодействие экономических, политических, социальных и духовных условий жизни людей, взаимодействие между собой различных характеристик этих людей (потребностей, интересов, ценностных ориентаций, правовых установок и т.д. $)^{4}$.

В своем ежегодном выступлении 28 апреля 2011 года в Совете Федерации Федерального Собрания Российской Федерации Генеральный прокурор России отметил, что, без сомнения, глобальную угрозу государству и обществу на сегодняшний день представляет терроризм ${ }^{5}$.

11 мая 2011 года на совещании по вопросам безопасности, Президент Российской Федерации Д.А. Медведев сказал так: «В конечном счёте определённые события, которые происходят за границей, могут непосредственным образом отражаться и на наших интересах, и на событиях внутри нашей страны. Ликвидация террористов, даже такого уровня, скажем, как недавно уничтоженный Бен Ладен, имеет прямое отношение к уровню безопасности на территории нашего государства. Не секрет, что известная террористическая сеть «Аль-Каида» регулярно засылала и продолжает засылать своих эмиссаров на территорию нашего государства. В результате

\footnotetext{
${ }^{3}$ Криминология. Под редакцией А.И.Долговой. 4 издание. М.2010. С.273-274.

${ }^{4}$ Криминология. Под редакцией А.И. Долговой. 4-е издание. M.2010. C. 299.

${ }^{5}$ Ежегодное выступление Генерального прокурора Российской Федерации перед членами Совета Федерации URL: http://www. genproc.gov.ru/news/news-71823/. 28.04.2011. 14.11.
}

специальных операций, которые проводятся нашими специальными службами и правоохранительными структурами, такого рода эмиссары регулярно уничтожаются. Поэтому эта взаимосвязь между международными событиями, действиями иностранных государств, урегулированием кризисов, которые возникают, и нашими внутренними событиями также должна быть в зоне нашего повышенного внимания, как на уровне Совета Безопасности, так и на уровне регулярной деятельности правоохранительных органов и других структур и подразделений, включая, естественно, Министерство иностранных дел...»

При анализе криминальной ситуации в Республике Ингушетия в 2000 -2010 гг., и, особенно по преступлениям террористического характера, целесообразно в основу периодизации положить время нахождения у власти того или иного Президента (Главы) Республики Ингушетия. Для республик СКФО это крайне важно, так как с личностью руководителя республики связаны региональные особенности реагирования на преступность, в том числе террористического характера. В целях выяснения вопроса о том, когда наиболее эффективно велась борьба с преступлениями террористического характера, были проанализированы периоды, когда руководителями Республики являлись следующие лица:

Руслан Аушев - 28 февраля 1993 года - 28 апреля 2002 года;

Мурат Зязиков - 23 мая 2002 года - 30 октября 2008 года;

Юнус-бек Евкуров - с 31 октября 2008 года 7

С 2002 по 2010 гг. по удельному весу преступлений террористического характера в структуре преступности Республика Ингушетия была на втором месте в России и уступала только Чеченской Республике. Большего всего зарегистрировано террористических преступлений за период 2000 - 2010 гг. и выявлено лиц, их совершивших было в Чеченской Республике ${ }^{8}$.

\footnotetext{
${ }^{6}$ Совещание по вопросам безопасности. 11 мая 2011 года, 16:00 Московская область, Горки. URL:http://kremlin.ru/news/11217. 15.05.2011. 00.38.

${ }^{7}$ URL:http://ru.wikipedia.org/wiki/\%D0\%98\%D0\%BD\%D0\%B $3 \% \mathrm{D} 1 \% 83 \% \mathrm{D} 1 \% 88 \% \mathrm{D} 0 \% \mathrm{~B} 5 \% \mathrm{D} 1 \% 82 \% \mathrm{D} 0 \% \mathrm{~B} 8 \% \mathrm{D} 1 \% 8 \mathrm{~F}$ \#ci te_note-Deportation_RIAN-36. 15.06.2011. 15.53.

${ }^{8}$ B 2009 г. в Чеченской Республике удельный вес преступлений террористического характера (d-9,3\%), превышал аналогичные показатели в РФ (d-0,02\%)- в 464,9 раза, в Республиках Дагестан (d-0,354\%) - в 26,3 раза и Ингушетии (d-1,78\%) - в 5,2 раза.
} 
Динамика зарегистрированных преступлений террористического характера, их удельный вес, а также выявленных лии, совершивших эти преступления в РФ, Республиках Дагестан (РД) и Ингушетии (РИ) и Чеченской Республике (ЧР) в 2000-2010 г2."

\begin{tabular}{|c|c|c|c|c|c|c|c|c|c|c|c|c|}
\hline \multirow[t]{2}{*}{ Годы } & \multicolumn{4}{|c|}{$\begin{array}{c}\text { Зарегистрировано преступле- } \\
\text { ний по ст.ст. 205,205-1,205- } \\
2,206,208,211,277,278,279, \\
280,282-1,282-2,360\end{array}$} & \multicolumn{4}{|c|}{$\begin{array}{c}\text { Выявлено лиц, совершивших } \\
\text { преступления, по ст.ст. 205,205- } \\
\text { 1,205-2,206, 208,211,277, 278, } \\
\text { 279,280,282-1, } \\
\text { 282-2,360 }\end{array}$} & \multicolumn{4}{|c|}{$\begin{array}{c}\text { Удельный вес преступлений тер- } \\
\text { рористического характера }\end{array}$} \\
\hline & РФ & РД & ЧР & РИ & РФ & РД & ЧР & РИ & РФ & РД & ЧР & РИ \\
\hline 2000 & 546 & 16 & 445 & 0 & 291 & 84 & 139 & 0 & 0,02 & 0,10 & 9,24 & - \\
\hline 2001 & 546 & 11 & 448 & 1 & 199 & 17 & 114 & 2 & 0,02 & 0,07 & 6,50 & 0,06 \\
\hline 2002 & 564 & 15 & 371 & 4 & 269 & 53 & 136 & 8 & 0,02 & 0,11 & 5,90 & 0,24 \\
\hline 2003 & 866 & 10 & 746 & 27 & 334 & 33 & 225 & 10 & 0,03 & 0,08 & 10,38 & 1,75 \\
\hline 2004 & 538 & 12 & 392 & 28 & 225 & 25 & 133 & 23 & 0,02 & 0,11 & 7,00 & 1,88 \\
\hline 2005 & 645 & 58 & 428 & 34 & 409 & 48 & 256 & 14 & 0,02 & 0,42 & 6,29 & 2,05 \\
\hline 2006 & 777 & 49 & 542 & 46 & 630 & 38 & 473 & 28 & 0,02 & 0,30 & 8,64 & 2,40 \\
\hline 2007 & 758 & 28 & 520 & 22 & 587 & 20 & 465 & 15 & 0,02 & 0,19 & 9,13 & 1,05 \\
\hline 2008 & 638 & 52 & 463 & 11 & 530 & 42 & 394 & 1 & 0,02 & 0,42 & 10,12 & 0,48 \\
\hline 2009 & 654 & 44 & 437 & 41 & 517 & 31 & 393 & 10 & 0,02 & 0,354 & 9,298 & 1,78 \\
\hline 2010 & 581 & 63 & 320 & 35 & 402 & 36 & 254 & 7 & 0,02 & 0,54 & 6,99 & 1,82 \\
\hline Всего & 7113 & 358 & 5112 & 249 & 4393 & 427 & 2982 & 118 & & & & \\
\hline
\end{tabular}

Если за 2000-2010 гг. в Чеченской Республике было зарегистрировано 5112 преступлений террористического характера, выявлено 2982 лиц, то в Республике Ингушетия за тот же период 249 преступлений и 118 лиц $^{10}$.

В 2010 г. в Чеченской Республике удельный вес преступлений террористического характера (d-6,99\%), превышал аналогичные показатели в РФ (d-0,02\%) в 349,5 раза, в Республиках Дагестан (d-0,54\%) в 12,9 раза и Ингушетии (d-1,82\%) - в 3,8 раза. За 2010 год в России было совершено 581 преступление

\footnotetext{
9 Числовые показатели в таблице проставлены сотрудником отдела информационно-аналитического обеспечения деятельности органов прокуратуры НИИ Академии ГП РФ юристом 1 класса Звягиной В.И.

${ }^{10}$ Самое большое количество лиц было выявлено в 2006 г. -473 , 2007 г. - 465, 2008 г. - 394, 2009 г. - 393. Числовые показатели представлены сотрудником отдела информационно-аналитического обеспечения деятельности органов прокуратуры НИИ Академии ГП РФ юристом 1 класса Звягиной В.И.
}

террористического характера, что на 11,2 \% меньше, чем в 2009 г. (654 преступления). В 2010 году удельный вес преступлений террористического характера в структуре преступности Республики Ингушетия $(1,82 \%)$ превышал аналогичный показатель в РФ в 91 раз (0,02\%), в Республике Дагестан $(0,54 \%)-$ в 3,4 раза, но был ниже в 3,8 раза, чем в Чеченской Республике.

На динамику регистрации преступлений террористического характера и количества выявленных лиц в указанные три периода оказывали влияние также следующие региональные особенности действия причинных комплексов: 1) проведение контртеррористической операции (КТО) в Чеченской Республике (1999-2009), 2) наличие большого количества беженцев на территории Республики Ингушетия из Чеченской Республики, 3) изменения в уголовном и процессуальном законодательстве: принятие нового УПК РФ, введенного с 1 июля 2002 года, и изменения диспозиции ст.205 УК РФ 
в 2006 году, 4) региональная политика руководства Республики Ингушетия по отношению к борьбе с преступлениями террористического характера, особенность которой также заключалась в принадлежности к различным силовым, правоохранительным органам всех троих Президентов (Глав): Р. Аушев - генерал - лейтенант Министерства обороны РФ, М. Зязиков - генерал- майор ФСБ России, Юнус -бек Евкуров - генерал - майор Главного разведывательного управления Генерального штаба Министерства обороны Российской Федерации (ГРУ ГШ МО РФ), 5) активность организованных преступных формирований террористического характера, которые широко использовали возможности для совершения организованных террористических преступлений на территории Республики Ингушетия, 6) наличие государственной границы протяженностью 35 км с Республикой Грузия, 7) последствия депортации (высылки) ингушей 23 февраля 1944 года в ходе проведения операции «Чечевица», 8) последствия осетино-ингушского конфликта 1992 года, 9) «незаживающая кровоточащая рана» - последствия трагедии в школе №1 г. Беслана, когда террористы захватили в заложники и убивали школьников, их родителей и педагогов 1-3 сентября 2004 года (углубленное исследование не проводилось в виду ограниченности времени командировки). Среди террористов было 10 этнических ингушей $\left.{ }^{11}, 10\right)$ интенсивность поступления денежных средств из внутренних и внешних источников для организации террористической деятельности, 11) проблемы ме-

${ }^{11}$ Извлечение из обвинительного заключение по уголовному делу № 20/870 по обвинению Кулаева Нурпаши Абургкашевича в совершении преступлений, предусмотренных ст.ст. 209 ч.2, 205 ч. 3, 206 ч. 3, ст. 30 ч. 3, ст. 206 ч. 3, 105 ч. 2 п.п. «а», «б, «в», «Д», «е», «ж», «३»), ст. 30 ч. 3, ст. 105 ч. 2 п.п. «а, б, в, д, е, ж, 3», 317; 222 ч. 3 УК РФ. «...Участниками банды были убиты 10 сотрудников правоохранительных органов, участвовавших в проведении контртеррористической операции по освобождению заложников, и 2 сотрудников МЧС, а 55 сотрудников правоохранительных органов, военнослужащих Министерства обороны Российской Федерации и Федеральной службы безопасности Российской Федерации получили ранения. В результате преступных действий членов банды направленных на устрашение населения путем уничтожения и повреждения зданий, сооружений и имущества, принадлежащего гражданам, здание муниципальной средней общеобразовательной школы №1 было разрушено, близлежащим зданиям государственных и иных учреждений, а также гражданам причинен значительный материальный ущерб на общую сумму 34 миллиона 025 тысяч 256 рублей 07 копеек. В ходе пресечения преступных действий членов банды сотрудниками правоохранительных органов, 31 участник банды были уничтожены, а Кулаев Н.А. задержан. ...». жэтнических отношений: на границе с Республикой Северная Осетия Алания и Чеченской Республикой (ФКПП»Кавказ») до настоящего времени имеются контрольно-пропускные пункты (КПП), укомплектованные полицейскими из других регионов России (на момент командировки - из Кемерово, часть полицейских проанкетирована по проблемам БФТ). Возможность беспрепятственного проникновения на территорию Республики Ингушетия из Чеченской Республики в период «зеленки» (весна, лето, осень).

Анализ зарегистрированных преступлений и выявленных лиц по ст.205 УК РФ в Республике Ингушетия свидетельствовал о том, что даже в период КТО в Чеченской Республике, когда Президентом был Р. Аушев (28 февраля 1993 года - 28 апреля 2002 года) количество зарегистрированных преступлений и выявленных лиц были минимальными (2002 г.- зарегистрировано 1 преступление, выявлено 2 лица).

Наибольшее количество зарегистрированных террористических актов было в Республике Ингушетия в период президентства М. Зязикова (23 мая 2002 года - 30 октября 2008 года). Можно привести хронологию антитеррористических операций, свидетельствовавшую об активности правоохранительных органов и спецслужб ${ }^{12}$. В 2006 году было зарегистрировано 30 преступлений по ст.205 УК РФ, но выявлено только 4 лица.

В период Президентства Юнус-бека Евкурова (Юнус-бек Евкуров - с 31 октября 2008 года) было зарегистрировано в 2009 - 2, 2010 г. - 1 преступление по ст.205 УК РФ, выявленных лиц не было. Динамика снижения зарегистрированных террористических актов с 2006 года также была объективно связана с изменением диспозиции статьи 205 УК РФ.

Всего за 2000-2010 гг. (по данным Информационного центра МВД РИ) было зарегистрировано 105 преступлений по ст.205 УК РФ, раскрыто 41 преступление, выявлено 46 лиц. Средний процент раскрываемости террористических актов $47 \%$, то есть почти половина. По представленным

\footnotetext{
${ }^{12}$ Хронология антитеррористических операций в Ингушетии в 2003-2007 гг. URL:http://antiterror.ru/.05.02.2011.01.23. В марте 2006 года в Назрани в ходе спецоперации был уничтожен боевик, входивший в бандгруппу арабского наемника Абу-Дзейта и подозревавшийся в причастности к похищению депутата Национального собрания Ингушетии Магомеда Чахкиева. В ночь на 10 июля 2006 года в Ингушетии был уничтожен один из самых одиозных главарей чеченских боевиков Шамиль Басаев, за которым российские спецслужбы охотились несколько лет.
} 


\section{Национальная безопасность 3(26) • 2013}

Информационным центром МВД Республики Ингушетия данным можно составить «криминологический портрет» лиц, совершавших террористические акты в Республике Ингушетия: это лица мужского пола в возрасте 25-29 лет, со средним образованием, без постоянного источника дохода.

Анализ данных выявленных лиц, совершивших преступления, предусмотренные статьей 205 УК РФ (2000-2002 гг.) в Республике Ингушетия свидетельствовал о том, что в период, когда Президентом был Р. Аушев (28 февраля 1993 года - 28 апреля 2002 года) выявлено было всего 2 лица по ст.205 УК РФ. В период президентства М. Зязикова (23 мая 2002 года - 30 октября 2008 года) было выявлено 52 лица по ст.205 УК РФ.

В период Президентства Юнус-бека Евкурова (с 31 октября 2008 года по настоящее время) не было выявлено лиц, совершивших преступление, предусмотренное ст.205 УК РФ. Всего за 2000-2010 гг. (по данным Информационного центра МВД РИ) было выявлено 54 лица, совершивших преступления, предусмотренное ст.205 УК РФ, 19 из которых привлечены к уголовной ответственности ${ }^{13}$.

Анализ результатов расследования уголовных дел по ст.208 УК РФ в Республике Ингушетия свидетельствовал о том, что в период, когда Президентом был Р. Аушев (28 февраля 1993 года - 28 апреля 2002 года) количество расследованных уголовных дел были минимальными (2001 г. - расследовано 4 уголовных дела по 4 преступлениям, 2002 г.- 3, выявлено 3 лица, направлено в суд 3 дела по 3 преступлениям).

Наибольшее количество расследованных преступлений по ст.208 УК РФ было в Республике Ингушетия в период президентства М. Зязикова (23 мая 2002 года - 30 октября 2008 года). В 2003 - 2008 гг. было расследовано 44 преступления по ст.208 УК РФ, направлено в суд 21 уголовное дело на 21 преступление на 22 обвиняемых.

В период Президентства Юнус-бека Евкурова (Юнус-бек Евкуров - с 31 октября 2008 года) было расследовано 41 преступление по ст.208 УК РФ: в 2009 - 18, 2010 г. - 23 преступление, направлено в суд 14 уголовных дел по 14 преступлениям на 15 лиц.

Всего за 2000-2010 гг. (по данным Информационного центра МВД РИ) было расследовано 92 уголовных дела по 92 преступлениям по ст.208

${ }^{13}$ Согласно данным ГИАЦ МВД РФ было выявлено всего 46 лиц по ст.205 УК РФ.
УК РФ, направлено в суд - 38 уголовных дел, прекращено в связи со смертью -28 дел (больше всего прекращено в связи со смертью в период президентства Юнус-бека Евкурова - 14, М. Зязикова - 10, Р. Аушева - 4 дела). По результатам расследованных уголовных дел за 2000-2010 гг. преступления, предусмотренные ст.208 УК РФ совершили лица в возрасте до 25 лет - 33, с 25 до 40 лет - 21, 40 лет и выше - 3 лица. 57 лиц имели среднее образование, 31 лицо - без постоянного источника дохода. Всего за 2000-2010 г. по представленным ИЦ МВД РИ данным было выявлено 134 лица, совершивших преступление, предусмотренное ст. 208 УК РФ, из которых в возрасте до 25 лет - 93 лица, от 25 до 40 лет - 40 лиц и свыше 40 лет -1 лицо. Из выявленных 134 лиц, 129 имели среднее образование и только 1 - начальное, 79 лиц - не имели постоянного источника дохода.

Таким образом, можно составить «криминологический портрет» участника НВФ в Республике Ингушетия: это лицо мужского пола, в возрасте до 25 - 40 лет, со средним образованием, без постоянного источника дохода.

Всего за 2000-2010 гг. по данным Информационного центра МВД РИ было зарегистрировано 130 преступлений по ст.208 УК РФ, раскрыто 92 преступления, выявлено 134 лица, средний процент раскрываемости $-89,3 \%$.

При общей оценке эффективности деятельности по реагированию правоохранительных органов на организованную террористическую деятельность следует иметь ввиду, что в с. Экажево Республики Ингушетия были нейтрализованы в 2006 году Ш.Басаев (период президентства М.Зязикова), идеолог международной террористической организации «Эмират Кавказ» в 2010 году - Саид Бурятский, 28 марта 2011 года нанесен ракетно - бомбовый удар по базе участников организованного преступного формирования (ОПФ) террористического характера, готовившего «террористов-смертников» в лесу Сунженского района Республики Ингушетия, где были нейтрализованы более 20 активных участников организованных преступных формирований (ОПФ) террористического характера, имеющего иерархосетевой характер (период, когда Главой Республики является Юнус-бек Евкуров).

Нашу позицию об иерархо-сетевом характере «Кавказского эмирата» разделяет американский профессор, эксперт по Северному Кавказу Гордон Хан известный также своей книгой «Российская исламская 
угроза». 28 сентября 2011 года в Центре международных стратегических исследований в Вашингтоне он заявил о том, что «...считает несостоятельными и не соответствующими действительности предположения о том, что Имарат Кавказ - продукт российских спецслужб, существующий исключительно в виртуальном мире...Правда заключается в том, что Имарат Кавказ - это структуированная иерархическая сеть, где амиры (лидеры) вилайятов (территорий) назначаются и подчиняются амиру Доке Умарову, которому они приносят баят (клятву верности). Сама структура организации определена омрой (указом) Умарова и представляет собой типичную сетевую форму. Есть четкое разделение на вилайяты (регионы), границы которых почти везде совпадают с административными границами республик. Каждый вилайят в свою очередь разделен на фронты - зоны ответственности амиров местного уровня...» ${ }^{14}$.

Анализ статистики свидетельствовал о том, что количество террористических актов в структуре преступлений террористического характера зарегистрированных в 2003-2006 гг. (в период президентства М. Зязикова) и выявленных лиц был даже выше, чем по ст.208 УК РФ (НВФ) за исключением 2006 г. (4 лица по ст.205 УК РФ и 10 лиц по ст.208 УК РФ), что объективно свидетельствовало о более активной и результативной борьбе с лицами, совершавшими преступления террористического характера, особенно террористические акты. Превышение удельного веса террористических актов по сравнению с НВФ в структуре преступности Рес - публики Ингушетия в 2003-2006 гг. являлось еще одной особенностью и свидетельствовало о большой общественной опасности как самих преступлений, так и лиц, их совершавших. Следует также учитывать, что это происходило в период контртеррористической операции (КТО) в Чеченской Республике (1999-2009 гг.) и активного сопротивления участников организованных преступных формирований силам правопорядка, которые совершали посягательства не только на сотрудников правоохранительных органов, военнослужащих, но и судей: было убито два Заместителя председателя Верховного суда Республики Ингушетия. 10 июня 2009 года утром неизвестные открыли огонь по служебной «Газели» заместителя председателя

\footnotetext{
14 Фатима Тлисова. Имарат Кавказ и мировая революция. Известный американский эксперт по Северному Кавказу представил в Вашингтоне свой новый доклад. Среда, 28 сентября 2011. URL:http://www.voanews.com/russian/news/ImaratCaucasus-2011-09-28-130750883.html. 11.11.2011.
}

Верховного суда Ингушетии Азы Газгиреевой. Она была назначена на должность зампреда Верховного суда Ингушетии в октябре 2008 года, сменив на этом посту также погибшего от рук бандитов Хасана Яндиева, которому выстрелили в спину. Предшественник Газгиреевой работал в республиканском Верховном суде с момента его основания - 1994 года, а вообще в судебной системе - более двадцати лет...» ${ }^{15}$. В то же время следует отметить, что в 2009-2010 г. существенно увеличилось количество выявленных лиц по ст.208 УК РФ 87 (период, когда Главой республики является Юнусбек Евкуров), чего ранее не наблюдалось.

По нашему мнению, обстановка в Республике Ингушетия остается крайне сложной, взрывоопасной, и не расходится с мнением профессионалов-военных. Вот, к какому выводу пришел генерал армии А.Куликов: «...Ингушетия не первый год находится в состоянии огромного напряжения. Период совместного существования с Чечней, неопределенность административных границ после разделения Чечено-Ингушетии, смешанность человеческих контактов, общность религиозного воспитания и традиций наложили свой отпечаток на последующее развитие республики. В период военных действий в Чечне боевики находили приют и поддержку на территории Ингушетии. Во дворце ее тогдашнего президента Руслана Аушева была персональная комната Масхадова. Президент Зязиков, начавший борьбу с бандподпольем, в ответ был подвергнут дискредитации, против него выдвинуты обвинения в коррупционности окружения (что является общим местом для всех кавказских республик). Покушения на членов семьи, волнения и митинги с требованием вернуть Аушева убедили федеральный центр заменить руководство и назначить Юнус-бека Евкурова, который развернул как борьбу с коррупцией, так и антитеррористическую работу. Такая деятельность нового главы республики вызвала очередной виток террористической активно-

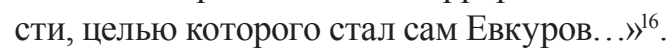

\footnotetext{
15 Алена Ларина. Пуля для судьи. Магас. URL:http:/www. rg.ru/2009/06/10/reg-kuban/ubiistvo-zampred.html. 17.06.2011. 14.19. «Российская газета» - www.rg.ru. 10.06.2009, 18:09. Основная версия убийства Азы Газгиреевой как и в случае с ее предшественником - служебная деятельность. Пока уголовное дело возбуждено по двум статьям 295 («Посягательство на жизнь лица, осуществляющего правосудие») и 222 («Незаконное хранение ношение оружия и боеприпасов») УК РФ.

${ }^{16}$ Кавказский гордиев узел. 29 апреля 2011. 20 апреля в Клубе военачальников Российской Федерации состоялось заседание «круглого стола» на тему «Северный Кавказ: итоги противодействия терроризму и аспекты борьбы с ним». Тон дискуссии
} 


\section{Национальная безопасность 3(26) • 2013}

В 2010 году в России наиболее резонансные террористические акты были совершены в московском метро, на ипподроме в Нальчике, в Ставрополе, Владикавказе, Пятигорске, в Республиках Дагестан и Ингушетии ${ }^{17}$.

На территории республики по данным ИЦ МВД по РИ в январе - декабре 2010 года зарегистрировано 1 (АППГ-2) преступление террористического характера, предусмотренное ч.3 ст.205 УК РФ. (АППГ-2) Квалификация по ст.205 УК РФ в данном конкретном случае является законной и обоснованной, что нельзя сказать о других аналогичных случаях в соседних республиках ${ }^{19}$.

задал доклад президента клуба генерала армии Анатолия Куликова. URL: http://www.chekist.ru/article/3642. 25.06.2011. 12.39.

${ }^{17} \mathrm{~K}$ резонансным преступлениям, связанным с деятельностью организованных преступных формирований в 2009 г., необходимо отнести убийство 10 июня 2009 г. зампредседателя Верховного суда республики Азы Газгиреевой, убийство 15 июня 2009 в Ингушетии бывшего вице-премьера республики и экс-секретаря Совета Безопасности Б. Аушева, посягательство на Президента Республики Ингушетии Юнус-Бека Евкурова 22 июня 2009 г. Ранжирование субъектов в СКФО по количество зарегистрированных террористических актов (16 преступлений) выглядело так: Республика Дагестан -10 (+233,3\%), Ставропольский край-3 (-), Республика Ингушетия -1 (-50), Кабардино-Балкарская Республика -1 (-), Республика Северная Осетия Алания -1 (-), Чеченская Республика -0 (-100\%), Карачаево-Черкесская Республика -0 (-) преступлений.

${ }^{18}$ По фактам взрывов Карабулакским городским следственным отделом следственного управления Следственного комитета по Республике Ингушетия возбуждено уголовное дело по признакам преступлений, предусмотренных п. «б» ч. 3 ст. 205 УК РФ (террористический акт, повлекший умышленное причинение смерти человеку) ст. 317 УК РФ (посягательство на жизнь сотрудника правоохранительного органа), ст. 295 УК РФ (посягательство на жизнь лица, осуществляющего правосудие или предварительное расследование), ч. 2 ст. 167 УК РФ (умышленное уничтожение или повреждение имущества путем поджога, взрыва или иным общеопасным способом либо повлекшие по неосторожности смерть человека или иные тяжкие последствия), ч. 2 ст. 222 УК РФ (незаконный оборот оружия, его основных частей, боеприпасов, взрывчатых веществ и взрывных устройств, совершенный группой лиц по предварительному сговору). URL: http://www.sledcom.ru/news/17402. html?sphrase_id=92322. (дата обращения 21.11.2011).

19 При ранжировании субъектов в СКФО по количеству зарегистрированных террористических актов следует иметь ввиду, что не все самоподрывы «смертников» были квалифицированы по ст.205 УК РФ, например: 30 июня 2010 г. самоподрыв в центре Грозного, недалеко от государственного театральноконцертного зала, осуществил 22-летний Адам Хамидов. 29 августа 2010 г. 2010 г. в ходе нападения на Центорой, родовое село президента Чечни Рамзана Кадырова, семь участников вооруженного подполья привели в действие закрепленные на
Даже представители СМИ пришли к выводу о том, что самоподрывы «смертников» необходимо считать (квалифицировать даже на первоначальном этапе досудебного следствия как террористический акт) ${ }^{20}$. По их подсчетам в результате 22 терактов, совершенных в 2010 году на территории Северо-Кавказского федерального округа и в Москве, погибли 108 человек и еще более 652 были ранены, а жертвами терактов и самоподрывов «смертников» стали 939 человек ${ }^{21}$.

По данным правозащитных организаций, после отмены контртеррористической операции (КТО) в «горячих» регионах Северного Кавказа - Чечне, Ингушетии и Дагестане - произошло 22 теракта с участием 24 смертников ${ }^{22}$, в результате этого погибли в общей сложности 92 человека, 414 получили ранения ${ }^{23}$. Таким образом, часть террористических актов была завуалирована под другие особо тяжкие преступления, предусмотренные ст.105, 317 УК РФ.

В 1 половине 2011 года в Республике Ингушетия улучшилась борьба с преступлениями террористического характера: было зарегистрировано 36 преступлений террористического характера (+176,9\%), предварительно расследовано преступлений $-28(+75,0 \%)^{24}$. В январе - декабре 2010 года

их телах радиоуправляемые взрывные устройства. 19 октября 2010 г. трое боевиков проникли на территорию, прилегающую к зданию парламента Чечни. В результате подрыва одного из них погибли два сотрудника правоохранительных органов, охранявших здание, а также завхоз. Двое других боевиков подорвались уже внутри парламента в ходе последовавшей перестрелки с силовиками. По факту нападения на здание парламента было возбуждено уголовное дело по признакам преступлений, предусмотренных шестью статьями УК РФ, но статьи 205 (теракт) среди них не было.

${ }^{20}$ Следует отметить, что в 2009 году журналисты в своих публикациях все взрывы, произведенные «смертниками», не без оснований, несмотря на то, что эти преступления квалифицировались следственными органами по ст.317 и другим статьям УК РФ, исполнителей преступления в своих публикациях называли, по-прежнему, «террористы-смертники».

21 Жертвами терактов и подрывов смертников на Северном Кавказе и в Москве с января 2010 года стали 939 человек. янв. 27 2011, 14:25. URL:http://www.kavkaz-uzel.ru/. 29.01.2011. 14.41 .

${ }^{22}$ Следует отметить, что не все подрывы «смертников» были квалифицированы по ст.205 УК РФ, как террористический акт.

23 «Новые Известия». За 15 месяцев на Северном Кавказе произошло 25 терактов, направленных против мирного населения. авг.19.2010,15:33.URL: http://www.kavkaz-uzel.ru/. 25.08.2010. 22.47.

${ }^{24}$ Ранжирование федеральных округов по выявленным лицам, совершившим преступления террористического характера в 1 половине 2011 года, выглядело таким образом: СКФО -195 
судами республики рассмотрено 5 уголовных дел в отношении 13 лиц о преступлениях террористической направленности, предусмотренных ст.208 УК РФ. По другим составам преступлений террористического характера, предусмотренным статьями Уголовного кодекса Российской Федерации, за период 2009-2010 г.г., уголовные дела судами не рассматривались.

\section{Проблемы борьбы с финансированием терроризма в Республике Ингушетия}

Финансирование терроризма является высоко латентным преступлением: в Республике Ингушетия не было зарегистрировано ни одного преступления. За период с 2002 по 2003 годы в России не было зарегистрировано преступлений, квалифицируемых по ст. 205.1 УК РФ. В 2004 г. было уже зарегистрировано 5 преступлений. Только, начиная с 2007 г., в сводном отчете по России за январь-декабрь появился Раздел 2. «Сведения о преступлениях, связанных с террористической деятельностью» и в нем графа «связанных с финансированием акта терроризма либо террористической организации», содержащая сведения о 4 расследованных сотрудниками органов внутренних дел преступлениях. В 2008 г. было зарегистрировано 6 расследованных преступлений, из которых 5 сотрудниками органов внутренних дел. Не произошло роста числа этих преступлений в 2009 г.: из 5 предварительно расследованных преступлений, сотрудниками органов внутренних дел расследованы - 2, в 2010 г.- предварительно расследовано одно преступление сотрудниками ОВД. Таким образом, за 2007 - 2010 г. всего было расследовано 16 преступлений, связанных с финансированием акта терроризма либо террористической организации, из которых 12 - сотрудниками органов внутренних дел. За 6 месяцев 2011 года предварительно расследовано 2 преступления, связанных с финансированием акта терроризма либо терро-

(+ 32,7\%), ЮФО-1 (-), СФО -2 (0\%), ПФО-7 (-12,5\%), ЦФО-1 $(-80 \%)$, СЗФО -1 (0,0\%), ДФО -1 (-66,7\%), УФО -0 (-100\%). В СКФО ранжирование субъектов по выявленным лицам выглядело так: Чеченская Республика - 126 (+3,3\%), Республика Дагестан -39 (+387,5\%), Республика Ингушетия -12 (+100\%), Карачаево-Черкесская Республика -12 (+200\%), КабардиноБалкарская Республика $-6(+50 \%)$, Ставропольский край -0 (-) и Республика Северная Осетия Алания-0 (-100\%). ристической организации, сотрудниками ОВД 25. Согласно данным судебной статистики, за 2006 - 2010 г. по ст. 205.1 УК РФ было всего осуждено 24 лица, из которых 12 - по основной статье, 12 - по дополнительной ${ }^{26}$.

НИИ Академии Генеральной прокуратуры Российской Федерации было проведено в 2010-2011 гг. 2 этапа научных исследований по БФТ (борьба с финансированием терроризма) ${ }^{27}$. На основе исследований сотрудникам правоохранительных органов была предложена следующая программа борьбы с терроризмом и его финансированием. На вопрос о том, согласны ли Вы с такой программой борьбы с терроризмом в 2011 г.: 1.Внести изменения в ч.1 cт.51 Конституции РФ следующего содержания: «Никто не обязан свидетельствовать против себя самого, своего супруга и близких родственников, круг которых определяется федеральным законом, за исключением случаев совершения преступлений террористического характера». 2. Принять Федеральный закон «О борьбе с организованной преступностью». 3.Ввести изменения в ФЗ о выплате вознаграждения за информацию о финансировании терроризма. 4. Ввести изменения в ФЗ и не выдавать трупьл лии, совершивших любое преступление террористического характера. 5. Объявить амнистию (или обеспечить необходимую охрану) лицам, финансировавщим терроризм под угрозой убийства, в том числе близких родственников, если они будут изобличать в ходе следствия и на суде участников организованных преступных формирований террористического характера. Что можете еще добавить?

Ответы респондентов распределились следующим образом: «Да»- 143 (67,8\%), «нет»-47

\footnotetext{
${ }^{25}$ Выборочные данные из формы 282 за январь-июнь 2011 года. Раздел 2. Сведения о преступлениях, связанных с террористической деятельностью.

${ }^{26}$ Данные из формы №10 а представлены старшим научным сотрудником отдела проблем информационно-аналитического обеспечения деятельности органов прокуратуры, советником юстиции Колесниковой Н.В.

${ }^{27}$ На 1 этапе опрашивались в 2010 году следователи Следственного комитета РФ. В период служебной командировки работников НИИ Академии Генеральной прокуратуры Российской Федерации с 16 по 29 мая 2011 года было организовано и проведено анкетирование сотрудников правоохранительных органов, спецслужб, студентов Республики Ингушетия, Чеченской Республики и Республики Дагестан по актуальным вопросам БФТ. В Республике Ингушетия 178 (75,7\%) респондентов, в Чеченской Республике-44 (18,7\%), в Республике Дагестан-13 $(5,5 \%)$, всего 235 респондентов.
} 


\section{Национальная безопасность 3(26) • 2013}

(22,3\%), иное мнение высказали - 21 (10,0\%), всего ответили 211 лиц.

По экспертным оценкам исследования 2011 года, если лет десять назад на Северном Кавказе бандитам платило абсолютное большинство бизнесменов, то в настоящее время платят: $20 \%$ бизнесменов - ответили 70 или $32,6 \%$ респондентов, $40 \%$ - 45 или $20,9 \%$, $60 \%$ - 34 или $15,8 \%$, иное мнение высказали - 66 или $30,7 \%$ респондентов.

На вопрос о том, решена ли проблема выявления и привлечения к уголовной ответственности лидеров, активных участников и пособников организованных преступных формирований в Республике, респонденты ответили так: нет - 157 (71,4\%), да- 39 (17,7\%), иное мнение- 24 (10,9\%).

Из интервью работника прокуратуры, этнического ингуша, усматривается, что в организации террористической деятельности замешаны разведки других государств: «...Участие западных спецслужб, арабов явно видно. Ставят своих амиров и финансируют их. Влияет религиозный фактор в виде ваххабизма. Финансирование идет с запада. Имеются угрозы Главам Администраций, чтобы платили дань. Бандиты совершают разбои, похищение человека. Есть сложности и проблемы при расследовании преступлений террористического характера...».

В 1 половине 2011 года в Республике Ингушетия не было зарегистрировано террористических актов вообще, но на вопрос о том, «боитесь ли Вы стать жертвой преступления и какого? Большинство респондентов ответили - терроризма (145 или 40,6\%), кражи (75 или 21,0\%), похищение человека - (44 или 12,3\%), обмана потребителя - (44 или $12,3 \%)$, заказного убийства (44 или 12,3\%), сексуального посягательства (40 или 11,2\%), мошенничества (37 или $10,4 \%)^{28}$.

Таким образом, «шкала актуальности опасений населения» в Республике Ингушетия выстроилась следующим образом. На первом месте среди опрошенных лиц стояли опасения стать жертвой террористического акта. В то же время согласно опросу «Левада-центра», проведенного среди 1,6 тыс. граждан России, 77\% населения боятся стать жертвой теракта. Таким образом, в Республике Ингушетия опасения стать жертвой террористического акта в два раза ниже, чем в России. На 2 месте респонден-

\footnotetext{
${ }^{28}$ В мае 2011 года в СКФО проводилось анкетирование населения, проведено обобщение 448 анкет: в Республике Ингушетия - 357, Республика Дагестан - 35, Пятигорск - 56 анкет.
}

ты в Ингушетии поставили опасения стать жертвой кражи, на третьем - похищения человека (44 или $12,3 \%$ ), обмана потребителя - (44 или 12,3\%), заказного убийства - (44 или 12,3\%), на 4 - сексуальные посягательства, и только на 5 месте - мошенничества. «Шкала актуальности опасений населения» в Республике Ингушетия далее выглядела так: причинения телесных повреждений - (37 или 10,4\%), хулиганства -28 или 7,8\%, угона автомобиля -27 или $7,6 \%$, вымогательства (рэкета) - 18 или 5,0\%

\section{Выводы и предложения:}

1.Участников НВФ в Республике Ингушетия нельзя рассматривать изолированно от организованных преступных формирований (ОПФ) террористического характера, действующих в Чеченской Республике, Карачаево-Черкесской Республике, Республике Дагестан в виде банд, преступных сообществ (преступных организаций) и от международной террористической организации «Кавказский эмират» Д. Умарова. Поэтому следует активнее бороться с высокоорганизованными формами террористической деятельности, предусмотренными ст. 209, 210 УК РФ (а не только статьей 208 УК РФ) ${ }^{29}$.

2. Организованная экономическая преступность на Северном Кавказе и в других субъектах Российской Федерации является внутренним источником финансирования терроризма. Согласны с этим мнением 107 (48,9\%), не согласны 83 (37,9\%), иное мнение высказали - 29 или $13,2 \%$ респондентов в Республике Ингушетия.

3. Прокуроры должны знать основные способы выявления и расследования преступлений, связанных с финансированием терроризма: 1. В первую очередь, выявление и расследование преступлений, связанных с финансированием терроризма необходимо проводить по преступлениям террористического характера. Эффективность прокурорского надзора за расследованием уголовных дел, связанных с финансированием терроризма, повышается при

\footnotetext{
${ }^{29}$ На вопрос о том: «Актуальна ли, по вашему мнению, проблема борьбы с организованной преступностью в регионе?» большинство респондентов ответили, что борьба с организованной преступностью актуальна для Республики Ингушетия - 289 респондентов или 81,0\%. Это означает, что правоохранительные органы и спецслужбы Республики Ингушетия должны согласованно бороться, в первую очередь, против организованной преступности, ее высоорганизованных форм в виде банд, преступных сообществ (преступных организаций).
} 
координации и взаимодействии с военной прокуратурой. Прокуроры должны шире использовать новые полномочия, введенные Федеральным законом от 28.12.2010 N 404-Ф330.

Надзирающие прокуроры, следователи всех правоохранительных органов и спецслужб России, расследующих уголовные дела о преступлениях террористического характера, в том числе связанных с финансированием терроризма, должны иметь достаточно высокую общетеоретическую и специальную подготовку, основанную на изучении не только специальной уголовно-правовой, криминалистической, но и криминологической литературы, НИИ Академии Генеральной прокуратуры, в том числе совместно с Российской криминологической ассоциацией (РКА). 2. Вовторых, выявление и расследование преступлений, в том числе связанных с финансированием терроризма, необходимо проводить не только по преступлениям террористического характера, но и по другим преступлениям, таким как: незаконный оборот наркотиков, оружия, углеводородов, похищения человека, посягательства на жизнь сотрудника правоохранительного органа, военнослужащего, вымогательства и другим преступлениям (фальшивомонетничество и т.д.), где имеется оперативная информация о финансировании терроризма за счет указанного вида организованной преступной деятельности. 3. В-третьих, на основе анализа состояния законности систематически (не реже одного раза в полугодие) проводить проверки исполнения федеральными органами исполнительной власти, органами государственной власти субъектов Российской Федерации, органами местного самоуправления и их должностными лицами в пределах своей компетенции требований законодательства о противодействии терроризму, в том числе о приоритетном порядке осуществления профилактических мер, добиваясь реализации ими в полном объеме функций по выявлению, пресечению и устранению нарушений антитеррористического законодательства.

\footnotetext{
${ }^{30}$ Истребовать и проверять законность и обоснованность решений следователя или руководителя следственного органа об отказе в возбуждении, приостановлении или прекращении уголовного дела и принимать по ним решение в соответствии с настоящим Кодексом; (п. 5.1 введен Федеральным законом от 28.12.2010 N 404-Ф3), передавать уголовное дело или материалы проверки сообщения о преступлении от одного органа предварительного расследования другому и т.д.
}

4. Обеспечение действенного надзора за исполнением законов при осуществлении оперативно-розыскной деятельности. 5. Наладить систему сбора, накопления и обработки данных о нарушениях законодательства о противодействии терроризму и его финансированию. Наиболее актуальные и проблемные вопросы организации противодействия терроризму рассматривать на координационных и межведомственных совещаниях руководителей правоохранительных органов, а также постоянно действующих координационных совещаниях (ПДКС) по обеспечению правопорядка в субъектах Российской Федерации согласно Указу Президента Российской Федерации «О дополнительных мерах по обеспечению правопорядка» №1535 от 11 декабря 2010 года»³1. 6. В пенитенциарной системе России отбывают наказание 824 лица ${ }^{32}$, осужденных за преступления террористического характера. При проведении надзорных проверок выяснять вопросы о том, направлялись ли оперативные задания для выяснения источников и каналов финансирования по месту отбывания наказания лиц, осужденных за преступления террористического характера. 7. Проводить ОРМ с лицами, освобожденными из мест лишения свободы, за совершение преступлений террористического характера в целях выявления источников и каналов финансирования терроризма. 8. Важна деятельность прокуратуры по организации экстрадиции в Россию лиц, совершивших преступления террористического характера, ибо эти лица могут знать источники и каналы финансирования. 9. Совершенствование пограничного контроля. «...Эффективный пограничный контроль является ключом к эффективному осуществлению мер по борьбе с терроризмом во исполнение резолюции 1373 (2001), поскольку он представляет собой первую линию обороны против передвижения террористов через границы и незаконного трансграничного передвижения товаров и грузов...». 10. Пресечение неконтролируемого международного передвижения террористов и террористических групп. 11. Использование новейшего оборудования и технологий при ор-

\footnotetext{
${ }^{31}$ URL: http://kremlin.ru/acts/9794. (дата обращения: 24.10.2011).

32 По данным ФСИН РФ на 1 апреля 2010 г. в ИК отбывают наказание 824 лица, осужденных за преступления террористического характера: ст.205 УК РФ-322, ст.205-1 УК РФ-11, ст.205-2 УК РФ-7, ст.206 УК РФ-101, ст.208 УК РФ-372, ст.277 УК РФ-11.
} 
ганизации контроля за передвижением граждан между государствами, и обмен информацией в режиме реального времени ${ }^{33}$.

В борьбе с преступностью в целом, и преступлениями террористического характера в Республике Ингушетия, в частности, возрастает роль научных знаний. В прокуратуре Республики Ингушетия проходят службу два кандидата юридических наук, руководство прокуратуры является соискателями в Академии Генеральной прокуратуры Российской Федерации. В Управлении ФСБ России по Республике Ингушетия в 2011 году была введена должность помощника начальника Управления по научной работе. Начальник Управления ФСБ России по Республике Ингушетия В.Н. Гурба в июле 2011 года защитил диссертацию на соискание ученой степени доктора социологических наук по теме «Терроризм в регионах адатных культур (на примере Северо-Кавказского Региона) $)^{34}$.

Представляется целесообразным и перспективным введение аналогичной должности и в других правоохранительных органах Республики Ингушетия и субъектах СКФО, ибо остается верной мудрость древних:

«Scientia vinces» («Наукой победишь»).

\section{Библиография:}

1. Стратегия национальной безопасности Российской Федерации до 2020 года. Утверждена Указом Президента Российской Федерации от 12 мая 2009 г. № 537. http://www.scrf.gov.ru/ documents/99.html. 04.12.2011.

\footnotetext{
33 Письмо Председателя Комитета Совета Безопасности, учрежденного резолюцией 1373 (2001) о борьбе с терроризмом, от 17 августа 2011 года на имя Генерального секретаря. Организация Объединенных Наций S/2011/463.Совет Безопасности. Distr.: General. 1 September 2011. «В соответствии с резолюцией 1963 (2010) Совета Безопасности Исполнительным директоратом Контртеррористического комитета на основе информации, имевшейся в его распоряжении по состоянию на май 2011 года, представлен обновленный глобальный обзор осуществления резолюции 1373 (2001) Совета Безопасности.». Глобальный обзор осуществления государствами-членами резолюции 1373 (2001) Совета Безопасности. Пункт 260. URL: http://translate.google.ru/translate?hl=ru\&lan gpair=en \% 7Cru\&u=http:/www.aspn.gov.me/ResourceManager/ FileDownload.aspx\%3FrId\%3D86893\%26rType\%3D2. (дата обращения:13.11.2011).

${ }^{34}$ Гурба Владимир Николаевич. Автореферат диссертации на соискание ученой степени доктора социологических наук. Новочеркасск.2011. 32 C.
}

2. Подписан закон, устанавливающий уголовную ответственность за незаконное создание юридического лица через подставных лиц. 7 декабря 2011 года, 15:15. Президент подписал Федеральный закон «О внесении изменений в Уголовный кодекс Российской Федерации и статью 151 Уголовно-процессуального кодекса Российской Федерации». Федеральный закон принят Государственной Думой 22 ноября 2011 года и одобрен Советом Федерации 29 ноября 2011 года. http://kremlin.ru/news/13888. (дата обращения: 08.12.2011).

3. Криминология. Под редакцией А.И.Долговой. 4 издание. М.2010. С.273-274.

4. Криминология. Под редакцией А.И.Долговой. 4-е издание. М.2010. С. 299.

5. Ежегодное выступление Генерального прокурора Российской Федерации перед членами Совета Федерации URL: http://www.genproc.gov.ru/news/ news-71823/. 28.04.2011. 14.11.

6. Совещание по вопросам безопасности. 11 мая 2011 года, 16:00 Московская область, Горки. URL:http://kremlin.ru/news/11217. 15.05.2011. 00.38 .

7. Хронология антитеррористических операций в Ингушетии в 2003-2007 гг. URL:http://antiterror. $\mathrm{ru} / .05 .02 .2011 .01 .23$.

8. Фатима Тлисова. Имарат Кавказ и мировая революция. Известный американский эксперт по Северному Кавказу представил в Вашингтоне свой новый доклад. Среда, 28 сентября 2011. URL:http://www.voanews.com/russian/news/ Imarat-Caucasus-2011-09-28-130750883.html. 11.11.2011.

9. Алена Ларина. Пуля для судьи. Магас. URL:http:// www.rg.ru/2009/06/10/reg-kuban/ubiistvo-zampred. html. 17.06.2011. 14.19. «Российская газета»www.rg.ru. 10.06.2009, 18:09.

10. Кавказский гордиев узел. 29 апреля 2011. 20 апреля в Клубе военачальников Российской Федерации состоялось заседание «круглого стола» на тему «Северный Кавказ: итоги противодействия терроризму и аспекты борьбы с ним». Тон дискуссии задал доклад президента клуба генерала армии Анатолия Куликова. URL: http://www. chekist.ru/article/3642. 25.06.2011. 12.39.

11. Жертвами терактов и подрывов смертников на Северном Кавказе и в Москве с января 2010 года стали 939 человек. янв. 27 2011, 14:25. URL:http:// www.kavkaz-uzel.ru/. 29.01.2011. 14.41. 
DOI: $10.7256 / 2073-8560.2013 .3 .5250$

При цитировании этой статьи сноска на dоі обязательна

Внутренний контур национальной безопасности

12. «Новые Известия». За 15 месяцев на Северном Кавказе произошло 25 терактов, направленных против мирного населения. авг.19.2010,15:33. URL: http://www.kavkaz-uzel.ru/. 25.08.2010.22.47.

13. URL : http://kremlin.ru/acts/9794. (дата обращения: 24.10.2011).

14. Письмо Председателя Комитета Совета Безопасности, учрежденного резолюцией 1373 (2001) о борьбе с терроризмом, от 17 августа 2011 года на имя Генерального секретаря. Организация Объединенных Наций S/2011/463. Совет Безопасности. Distr.: General. 1 September 2011. «В соответствии с резолюцией 1963 (2010) Совета Безопасности Исполнительным директоратом Контртеррористического комитета на основе информации, имевшейся в его распоряжении по состоянию на май 2011 года, представлен обновленный глобальный обзор осуществления резолюции 1373 (2001) Совета Безопасности.». Глобальный обзор осуществления государствами-членами резолюции 1373 (2001) Совета Безопасности. Пункт 260. URL: http://translate.google.ru/tran slate?hl=ru\&langpair=en $\% 7 \mathrm{Cru} \& \mathrm{u}=\mathrm{http}: / / \mathrm{www}$. aspn.gov.me/ResourceManager/FileDownload. aspx\%3FrId\%3D86893\%26rType\%3D2. (дата обращения:13.11.2011).
15. Гурба Владимир Николаевич. Автореферат диссертации на соискание ученой степени доктора социологических наук. Новочеркасск.2011. 32 C.

\section{References (transliteration):}

1. Kriminologiya. Pod redakciey A.I.Dolgovoy. 4 izdanie. M.2010. S.273-274.

2. Kriminologiya. Pod redakciey A.I.Dolgovoy. 4-e izdanie. M.2010. S. 299.

3. Hronologiya antiterroristicheskih operaciy $\mathrm{v}$ Ingushetii v 2003-2007 gg. URL:http://antiterror. $\mathrm{ru} / .05 .02 .2011 .01 .23$.

4. Fatima Tlisova. Imarat Kavkaz i mirovaya revolyuciya. Izvestnyy amerikanskiy ekspert po Severnomu Kavkazu predstavil v Vashingtone svoy novyy doklad. Sreda, 28 sentyabrya 2011. URL:http:// ww w.voanews.com/russian/news/ImaratCaucasus-2011-09-28-130750883.html. 11.11.2011.

5. Alena Larina. Pulya dlya sud'i. Magas. URL:http:// www.rg.ru/2009/06/10/reg-kuban/ubiistvo-zampred. html. 17.06.2011. 14.19. «Rossiyskaya gazeta»www.rg.ru. 10.06.2009, 18:09.

6. Gurba Vladimir Nikolaevich. Avtoreferat dissertacii na soiskanie uchenoy stepeni doktora sociologicheskih nauk. Novocherkassk.2011. 32 S. 